\title{
Application of Avinit vacuum plasma technologies Avinit to the manufacture of high-precision full-size gears
}

\author{
A. Sagalovych ${ }^{1} \bullet$ V. Popov ${ }^{1} \bullet$ V. Sagalovych ${ }^{1} \bullet$ S. Dudnik ${ }^{1} \bullet$ A. Edinovych ${ }^{2}$
}

Received: 20 February 2021 / Accepted: 24 May 2021

\begin{abstract}
Avinit duplex technologies have been developed, combining Avinit N plasma nitriding of finished high-precision parts with subsequent application of Avinit superhard antifriction coatings in a single technological process

Due to the absence of a brittle layer on the nitrided surface after precision nitriding, the preservation of the original geometric dimensions that do not require further mechanical refinement, and the compatibility of the processes of plasma precision nitriding of Avinit $N$ and the vacuum plasma deposition of functional coatings Avinit $C$, duplex technologies allow the deposition of strong adhered, high-quality coatings.

The effect of the duplex process on the dimensions of parts during plasma nitriding of high-precision gears and the application of Avinit $C$ functional coatings was investigated, the properties of the nitrided laver and the parameters of Avinit coatings were studied.

Plasma precision technology Avinit $N$ allows nitriding of finished parts without changing dimensions, including gears of 4 degrees of accuracy. Avinit $N$ nitriding time is $2 \ldots 4$ times less than with gas nitriding.

The coating of Avinit C310 parts increases the microhardness of the surfaces of the parts and reduces the coefficient of friction, while it has sufficient adhesion to the working surfaces of the gear teeth and bearing raceways.

Manufacturing of high-precision gears with accuracy grade 4 using Avinit duplex technologies was carried out.

Analysis of the results shows that, within the measurement accuracy, no changes in the profiles of the teeth, their location on the ring gear, as well as the location of the gear ring relative to the measuring bases are observed.

Plasma nitriding makes it possible to reduce the nitriding time by more than two times compared to gas nitriding, while the thickness of the layer of the brittle phase with the maximum surface hardness is ensured within the specified values to ensure the necessary indicators of contact and bending long-term strength in the manufacture of gears according to the degree of accuracy 4 without grinding after nitriding.

Measurements of the ring gear after nitriding and coating showed that there were no changes in the geometry of the gear processed by duplex technology. Avinit C310 anti-friction coating 1.5 microns thick does not distort the geometry of the tooth profiles. All parameters of the ring gear manufactured using the Avinit duplex technology correspond to accuracy grade 4 in accordance with the requirements of technical documentation.

The gears manufactured using the Avinit duplex technology were tested as part of the AI-450M engine reducer at the Ivchenko-Progress hydraulic brake stand according to the program of equivalent cyclic tests. A pair of experimental gears were installed in the engine reducer instead of the serial wheels of the second stage of the reducer. The total test time of the wheels was 26 hours. After testing, no damage to the gear, including the Avinit coating, was found. Antifriction coating Avinit C310 with a thickness of 1.5 microns does not distort the geometry of the tooth profiles during testing as part of the AI-450M engine reducer. Measurement of the parameters of the teeth showed a complete absence of wear.
\end{abstract}

Keywords: development of Avinit duplex technologies, properties of the nitrided layer, coating Avinit characteristics, bench tests of high-precision gears manufactured using Avinit duplex technology.

\section{Introduction}

At creation of new materials with ultrahigh characteristics technologies of modification of surface layers of contacting materials and drawing functional coverings are more and more successfully used.

A very important characteristic of structural materials is the long fatigue strength of the working surfaces of

\footnotetext{
$\triangle$ A.V. Sagalovych avinit@avinit.ua

${ }^{1}$ JSC “FED”, Kharkiv, Ukraine

${ }^{2}$ SE "Ivchenko Progress" Zaporizhya, Ukraine
}

gears and rolling bearings, which is determined by the properties of the materials from which they are made, in particular, the hardness of the material core, hardness of the working hardened surface, depth of the strengthened layer, surface roughness, coefficient of friction [1].

Typically, standard manufacturing technologies for many industrial parts designed to work in high-precision gears, hinges and plain bearings include pre-cementation, subsequent grinding and polishing of work surfaces to achieve the required geometric dimensions.

Nitriding is much less commonly used as a method of strengthening machine parts and tools to provide functional properties. 
The main disadvantages of traditional industrial nitriding technologies (gas furnace nitriding, liquid nitriding, etc.) are the presence of a solid brittle $\varepsilon$-phase on the nitrided surface and significant distortion of parts, which further grinding and polishing of work surfaces significantly reduces the contact strength of the surface and increases manufacturing complexity products.

Nevertheless, nitriding processes to increase contact endurance have significant prospects in comparison with traditionally used cementation processes in terms of increasing surface hardness, especially by eliminating machining after nitriding.

At the end of the twentieth century, the level of surface hardness for cemented and nitrided parts stabilized at about $60 \mathrm{HRC}$, but if for the former it was actually the limit, for the latter it was possible to increase hardness and, accordingly, contact endurance by eliminating machining after nitriding.

Diffusion saturation of the steel surface with nitrogen occurs at a temperature of about $550{ }^{\circ} \mathrm{C}$. which ensures the absence of phase transformations in steel, because the process takes place at a temperature below the temperature of low tempering after quenching. This significantly reduces the curvature and, consequently, the allowance removed during grinding.

The disadvantages of traditional industrial technologies for strengthening the surfaces of steel parts by the formation of metal nitrides in the surface layer are the long duration of the process $(2 \ldots 3$ times longer than during cementation) and the small depth of the diffusion layer [2].

Increasing the saturation rate is achieved by ionic nitriding in a dilute nitrogen atomic medium of the glow discharge, which reduces the process time by $1.5 \ldots 2$ times.

In works [3, 4] the possibility of manufacturing gears with a degree of accuracy from 6 to 5 without grinding after ionic nitriding is shown.

There are no data on the use of nitriding in the manufacture of more loaded gears, where it is necessary to use accuracy degrees 5...4 [5-7].

In [8-10] it was shown that even greater acceleration of the process than with ionic nitriding in a glow discharge occurs during plasma nitriding.

We have developed the process of plasma precision nitriding Avinit N [8-10], based on the diffusion saturation of the surface layer of steel parts with nitrogen in high-density ( $n \geq 10^{10}-10^{11} \mathrm{~cm}^{-3}$ ) low-temperature very nonequilibrium plasma of nitrogen and argon. significantly reduces the duration of nitriding, ensures the absence of deformation (curvature) of the parts while maintaining the original geometric dimensions after nitriding with an accuracy of 1-2 $\mu \mathrm{m}$, which avoids finishing grinding of parts and get the operation of precision nitriding "in size".

Studies [11, 12] have shown that the methods of plasma precision nitriding Avinit $\mathrm{N}$ have a high efficiency for the manufacture of final finished high-precision gears with a degree of accuracy of $5 . . .4$ without grinding after nitriding.
Comparative tribotechnical tests for contact fatigue strength during rolling friction with sliding of surfaces reinforced with cementation and plasma nitriding Avinit $N$ with contact loads $\sigma_{\max } \approx 1000 \mathrm{MPa}$ were carried out in [13].

The results of tests based on 1,000,000 cycles with contact loads $\sigma_{\max }=1140 \mathrm{MPa}$, typical for mediumloaded surfaces, showed that the integrated multi-cycle resistance to fatigue wear (destruction) of samples reinforced with nitriding Avinit $N$ with a layer depth of $0.25 \mathrm{~mm}$, more than 10 times higher than samples reinforced by cementation with a layer depth of $1.2 \mathrm{~mm}$.

A significant increase in contact endurance provides a reduction in the coefficient of friction of the contact surfaces.

\section{The use of plasma precision nitriding Avinit $\mathbf{N}$ for the manufacture of high-precision gears}

Works $[11,12]$ are devoted to the study of the possibility of using plasma precision nitriding Avinit $\mathrm{N}$ for the manufacture of finally finished high-precision gears with a degree of accuracy $5 \ldots 4$ without grinding after nitriding, the study of the effect of plasma nitriding on the size of parts in plasma nitriding gears nitrided layer, and the study of plasma precision nitriding Avinit N highprecision gears.

In order to study the properties of plasma nitriding, a gear with a degree of accuracy [11] was made.

The gear wheel is made of steel $34 \mathrm{NiCrMoV} 14-5$ with the following heat treatment before nitriding operation:

- quenching $-900{ }^{\circ} \mathrm{C}(3.5 \mathrm{~h})$;

- leave $-620^{\circ} \mathrm{C}(6$ hours $)$;

- vstabilizing leave after machining $-550^{\circ} \mathrm{C}$ (6 hours).

Plasma nitriding was performed on a vacuumplasma cluster Avinit [19].

The part was completely nitrided, and the degree of nitrogen saturation depended on the plasma concentration in a particular area of the part.

To determine the effect of nitriding on the geometric dimensions of the experimental part was measured before and after nitriding. The gear ring gear was measured.

The geometric dimensions of the gear ring sample were measured on the same control and measuring machine "WENZEL" with a measurement error of $0.8 \mu \mathrm{m}$ before and after nitriding under the same conditions, on the same teeth.

The measurement results are given in table 1.

The analysis of the results shows that within the accuracy of measuring any changes in the profiles of the teeth, their location on the toothed crown, as well as the location of the toothed crown relative to the measuring bases is not observed. 
Table 1. Measurements of the toothed crown.

\begin{tabular}{|c|c|c|c|c|c|c|c|c|c|c|}
\hline \multirow{4}{*}{$\begin{array}{c}\text { Name } \\
\text { parameter }\end{array}$} & \multirow{4}{*}{$\begin{array}{l}\text { Condition } \\
\text { ally } \\
\text { marking }\end{array}$} & \multicolumn{8}{|c|}{ Deviation of parameters, мкм } & Deviation limit \\
\hline & & \multicolumn{4}{|c|}{ to nitriding } & \multicolumn{4}{|c|}{ after nitriding } & \\
\hline & & \multicolumn{4}{|c|}{ Tooth number } & \multicolumn{4}{|c|}{ Tooth number } & 5th degree \\
\hline & & 1 & 23 & 43 & 66 & 1 & 23 & 43 & 66 & \\
\hline Tooth profile error & $\mathrm{F} \alpha$ & 4 & 5 & 3 & 3 & 5 & 5 & 4 & 3 & 8 \\
\hline Tooth line error & $\mathrm{F} \beta$ & 2 & 3 & 2 & 4 & 3 & 3 & 4 & 4 & 8,5 \\
\hline Accumulated step error & FP & \multicolumn{4}{|c|}{20} & \multicolumn{4}{|c|}{20} & 19 \\
\hline Borderline step deviation & $\gamma \mathrm{P}$ & \multicolumn{4}{|c|}{ \pm 4} & \multicolumn{4}{|c|}{ \pm 4} & \pm 7 \\
\hline
\end{tabular}

It was established [12], that the plasma precision nitriding of Avinit $N$ ensured the production of gears with a degree of accuracy of 5 without grinding after nitriding. Changes in the geometry after plasma high-precision nitriding Avinit $N$ is not observed, and all parameters of the ring gear meet the accuracy of 5 according to the requirements of the technical documentation. When nitriding, the parameters of the teeth of the gears are stably maintained within the accuracy of 5 . Some change in the profile was observed at the tops of the teeth, which is due to the increased electric potential in this area. Measurement of the part after plasma nitriding did not reveal a similar phenomenon, on the contrary, on the tops of the teeth there is a slight decrease in hardness, which, however, should have a positive effect on the performance of the gears.

In order to study the properties of plasma nitriding of gears, a technological sample based on a gear made of 5 degrees of accuracy was used, on which nitriding modes were tested and which was subjected to geometry measurements and metallurgical research [12].

On the technological sample made of the investigated gear after nitriding and measurements, metallurgical researches on definition of hardness, thickness of the nitrided layer, distribution of microhardness on a layer, microstructure of a layer and a core were carried out.

The appearance of the technological sample (fragment of the gear) is shown in Fig. 1.

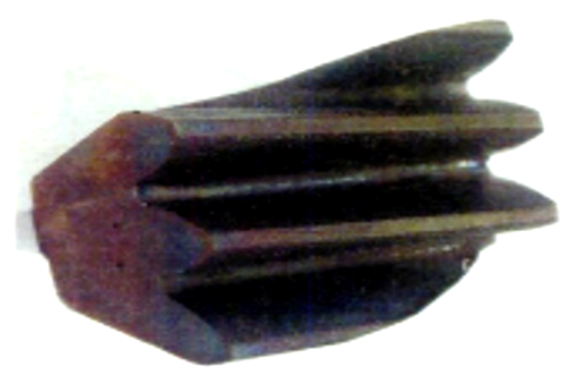

Fig. 1. Fragment of the gear
The measurement of the hardness of the nitrided layer, starting from the edge, was performed with a discreteness of $0.05 \mathrm{~mm}$ to a depth of $0.5 \mathrm{~mm}$ (table 2).

Table 2. The results of hardness measurements

\begin{tabular}{|c|c|c|}
\hline № & Distance from the edge, $\mathrm{mm}$ & Hardness, $\mathrm{H} \mu$ \\
\hline 1 & 0,025 & 709,5 \\
\hline 2 & 0,05 & 712,5 \\
\hline 3 & 0,10 & 679 \\
\hline 4 & 0,15 & 606 \\
\hline 5 & 0,20 & 565 \\
\hline 6 & 0,25 & 466,5 \\
\hline 7 & 0,30 & 434,5 \\
\hline 8 & 0,35 & 434,5 \\
\hline 9 & 0,40 & 431,5 \\
\hline
\end{tabular}

Cities for measuring the hardness of the readings in Fig. 2.

Microstructural analysis showed that the depth of the nitrided layer is $\sim 0.3 \mathrm{~mm}$, which meets the requirements of the technical documentation $(0.5 \ldots 0.7 \mathrm{~mm}$ initial minus $0.15 \mathrm{~mm}$ allowance for grinding), but with greater surface hardness (more than $1000 \mathrm{HV}$ ).

$\mathrm{X}$-ray diffraction analysis showed that the $\varepsilon$-Fe $3 \mathrm{~N}$ phase was not determined in the nitrided layer, and intense reflections of the a-Fe phase and very weak reflections of FeC carbide were detected (Fig. 3).

Plasma nitriding reduces the time required for nitrogen diffusion by more than twice compared to gas nitriding, while the thickness of the layer of brittle phase with maximum surface hardness is provided within the specified values to ensure the required indicators of contact and bending strength. 


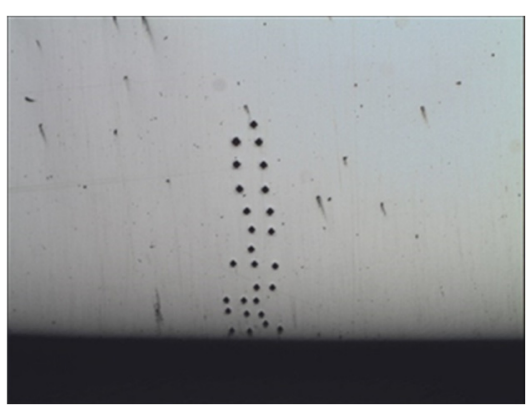

$a$

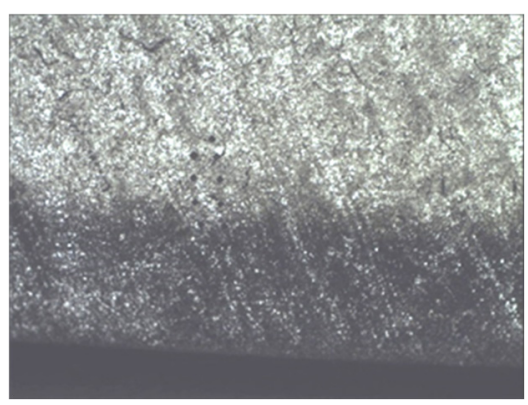

$b$

Fig. 2. Imprints of microhardness measurement $-a$ (the section is not etched), $-b$ (the section is etched)

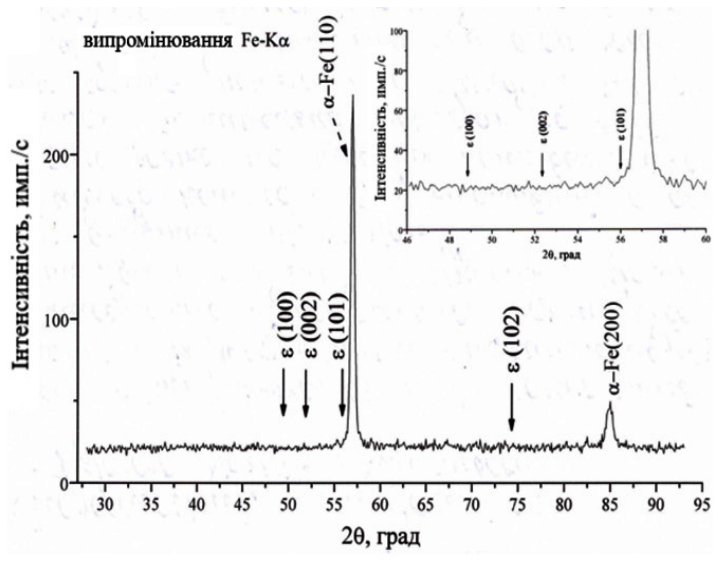

Fig. 3. Results of X-ray diffraction analysis of nitrided steel

2. Development of duplex technologies (plasma precision nitriding Avinit $N+$ hard coating Avinit C)

Even more significant results in increasing the contact long-term strength can be expected when applying antifriction coatings to the nitrided surface.

When using metal surface coatings (copper, palladium), such antifriction coatings have limited performance due to abrasive wear. In the 1990s, tungsten carbide-based ceramic hard coatings began to be introduced in the West.
JSC "FED" (Kharkiv, Ukraine) and STC "Nanotechnology" (Kharkiv, Ukraine) have developed complex coating technologies Avinit that combine in one cycle such methods as plasma-chemical, vacuum-plasma and others, which allow to obtain coatings from almost any elements, alloys, ceramics and other materials [14-16]. These technologies allow to perform multilayer antifriction coatings, for example, Avinit C310 [17, 18], which is a combination of nanolayers of titanium nitrides, aluminum nitrides and titanium. This coating has a unique coefficient of dry friction. The advantage of these technologies is also the ability to control the amount of heating of the part, which is mandatory with limited heat resistance of the coated materials. The developed technologies for applying Avinit multifunctional coatings have shown the high antifriction properties of Avinit coatings and high efficiency in many industrial applications when applied to critical parts in aggregate construction. transport engineering and power engineering $[19,20]$.

However, obtaining high-quality Avinit coatings on surfaces nitrided by traditional methods is associated with great difficulties, mainly due to the presence on the nitrided surface of a fairly thick layer of brittle $\varepsilon$ - phase and significant distortion of parts. To bring the dimensions to the requirements of the technical documentation after nitriding requires further grinding and polishing of work surfaces, which significantly reduces the contact strength of the surface and increases the complexity of manufacturing products. The mechanical parameters of this thick brittle layer are poorly compatible with the coating. and as it turned out, further vacuum-plasma application of highquality wear-resistant coatings is possible only with the complete removal of these fairly thick layers from the coated work surfaces. For complex surfaces, this becomes quite difficult and time-consuming, and sometimes simply unsolvable technical problem.

Our research has shown that the absence of a brittle surface layer after plasma nitriding allows further application of high-quality functional coatings Avinit without any mechanical improvements of the nitrided surface.

In this regard, it is of undoubted interest to develop duplex technology that combines plasma nitriding of finished high-precision parts with subsequent application of superhard antifriction coatings Avinit in a single process, which will avoid many difficulties associated with the use of gas nitriding technology used in the production of details.

Due to the absence of a brittle layer on the nitrided surface after precision nitriding, preservation of the original geometric dimensions that do not require further mechanical refinement, and compatibility of the processes of plasma precision nitriding Avinit N and vacuum-plasma application of functional coatings, Avinit duplex this significantly improves the economic performance of the manufacture of parts.

Duplex processes, including plasma nitriding and subsequent vacuum-plasma application of wear-resistant 
coatings in a single process, are carried out on a vacuumplasma cluster Avinit.

First, plasma precision nitriding of Avinit N parts $[8,9]$.is performed. Process parameters and its duration (usually $T \sim 500 \ldots 550{ }^{\circ} \mathrm{C}, t \sim 2 \ldots 4 \mathrm{~h}$ ) are determined based on the results of previous experiments.

By means of the corresponding electronic switching the Avinit installation is switched to a coating mode.

The temperature of the parts is reduced to the parameters required for vacuum-plasma coating of Avinit C $\left(T \sim 200 \ldots 300{ }^{\circ} \mathrm{C}, t \sim 1 \ldots 2 \mathrm{~h}\right.$ ) according to the established technology $[17,18]$.

Coating on the witness samples is carried out in conjunction with the working parts.

After the coating process, a careful control is carried out on the compliance of the thickness and microhardness of the applied coatings to the requirements of the technical documentation by metallographic and profilographic analyzes of the sections of the witness samples.

Changing the process parameters (pressure, temperature, time, discharge voltage) allows to provide the specified properties of nitrided surfaces. Reduction of nitriding time allows to make details of the increased accuracy.

On the JEOL 6360LA electron microscope, the Avinit coating on the surface of the nitrided layer was studied by the PCMA method.

The research results are presented in Fig. 4-6.

On the surface of the part the presence of titanium, aluminum, nitrogen, which are absent in the part made of steel 34NiCrMoV14-5, but present in the coating Avinit C310, which is a multilayer composition of layers of titanium, titanium nitride and aluminum nitride.

The thickness of the coating is $1.5 \mu \mathrm{m}$.

The microhardness of the coating was $2500 \ldots 3000 \mathrm{HV}$.

Developed Avinit duplex technologies, including plasma nitriding Avinit $\mathrm{N}$ and ion-plasma application of antifriction wear-resistant coatings $\boldsymbol{A}$ vinit $\mathrm{C}$ were applied to the manufacture of full-size high-precision gear in Fig. 7.
Changing the process parameters (pressure, temperature, time, discharge voltage) allows to provide the specified properties of nitrided surfaces. Reduction of nitriding time allows to make details of the increased accuracy.

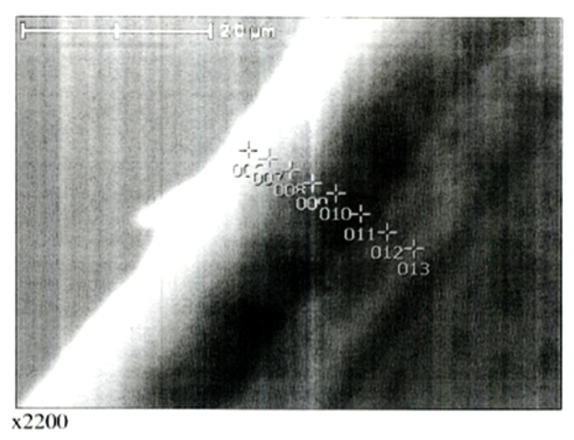

$a$

\begin{tabular}{|c|c|c|c|c|c|c|c|}
\hline Number & $\mathrm{N}$ & $\mathrm{Al}$ & $\mathrm{Si}$ & $\mathrm{Ti}$ & $\mathrm{Cr}$ & $\mathrm{Fe}$ & $\begin{array}{c}\text { Total, } \\
\%\end{array}$ \\
\hline 006 & 4,02 & 36,56 & & 59,42 & & & 100 \\
\hline 007 & 2,69 & 20,45 & & 76,87 & & & 100 \\
\hline 008 & 2,00 & 7,05 & & 90,94 & & & 100 \\
\hline 009 & 2,12 & 4,16 & & 93,72 & & & 100 \\
\hline 010 & 1,41 & 2,92 & & 86,81 & 1,23 & 7,63 & 100 \\
\hline 011 & & 1,08 & & 54,8 & 5,75 & 38,37 & 100 \\
\hline 012 & & & 0,27 & 16,47 & 9,85 & 73,41 & 100 \\
\hline 013 & & & 0,37 & 3,67 & 10,66 & 85,3 & 100 \\
\hline
\end{tabular}

Fig. 4. The appearance of the coating Avinit C310 on the sample with the specified places of analysis. - $a$, the approximate chemical composition of the analyzed places $-b$
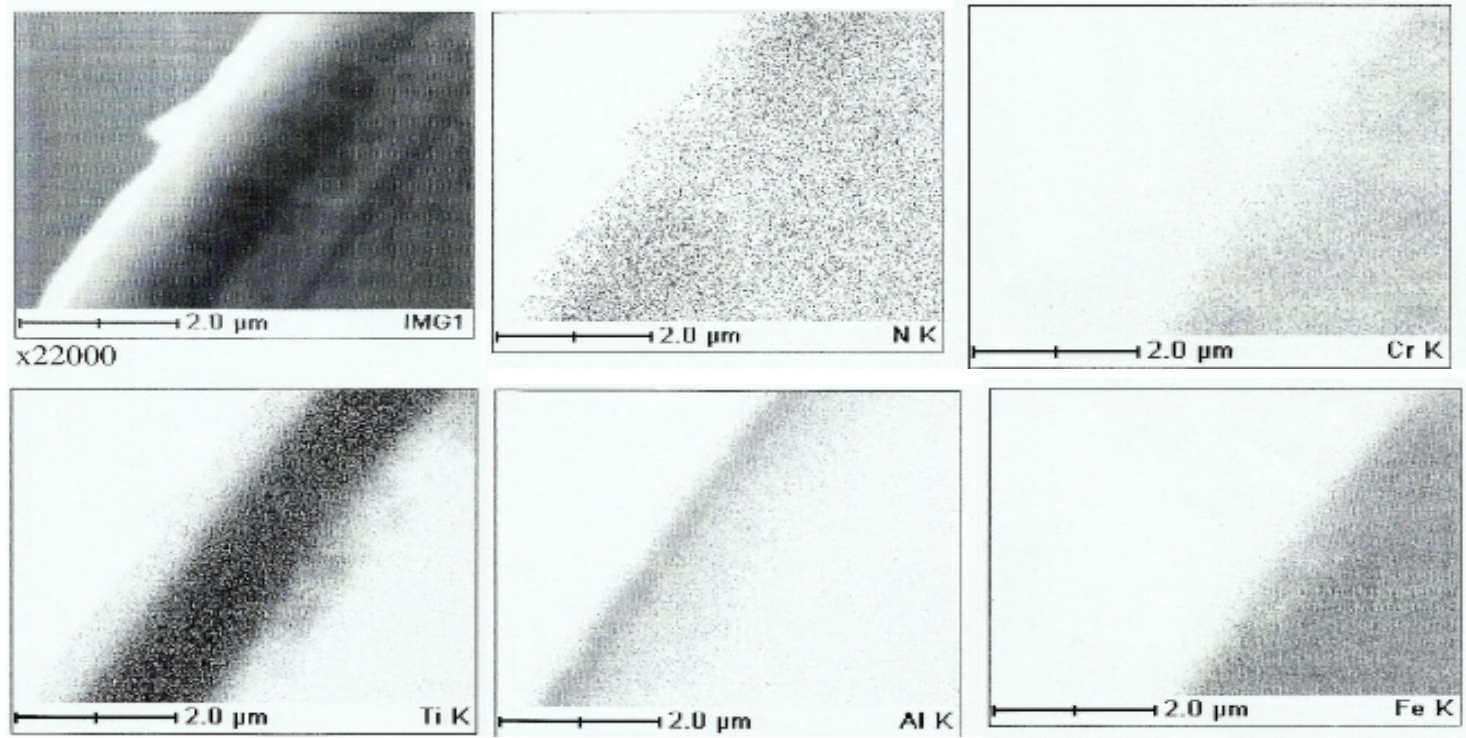

Fig. 5. Appearance of the Avinit C310 coating on the sample in mapping mode 

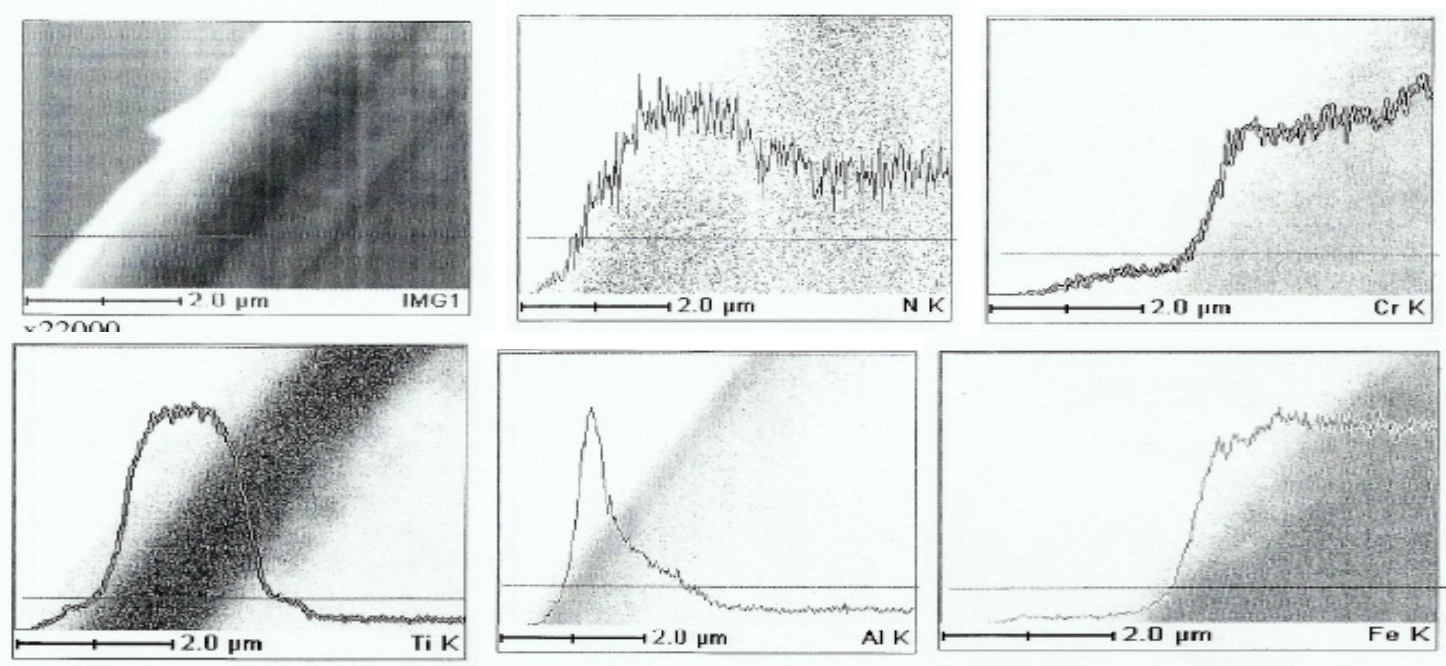

Fig. 6. Appearance of the Avinit $\mathrm{C} 310$ coating on the sample in line analysis mode. The thickness of the coating is $1.5 \mu \mathrm{m}$

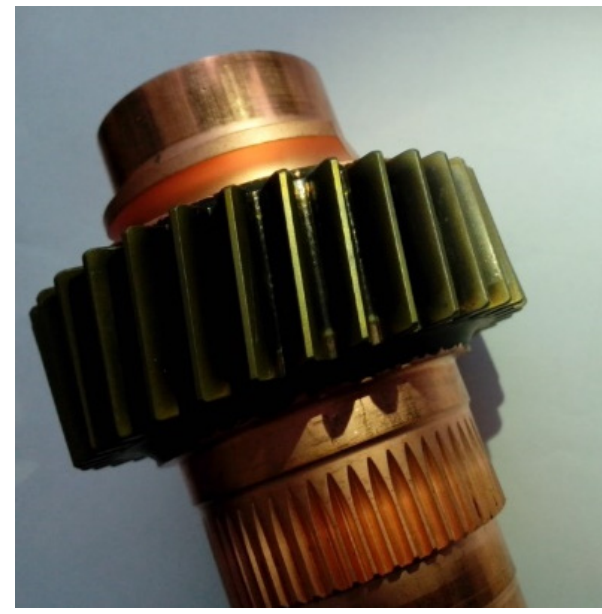

Fig. 7. Full-size high-precision gear, made using duplex technology Avinit (nitriding Avinit N + coating Avinit C310)

After carrying out work on testing the nitriding of the gear, made with 5 degrees of accuracy, was made experimental full-size high-precision helical gear [21] with a degree of accuracy of 4 for plasma nitriding, followed by application of antifriction coating Avinit C310.

In accordance with the developed technological regulations, plasma precision nitriding of Avinit N and subsequent application of antifriction coating Avinit C310 full-size high-precision gear by duplex technology was carried out ().

When nitriding a full-size gear, a witness sample was used (Fig. 8), on which nitriding regimes were tested and which was subjected to metallurgical research [21].

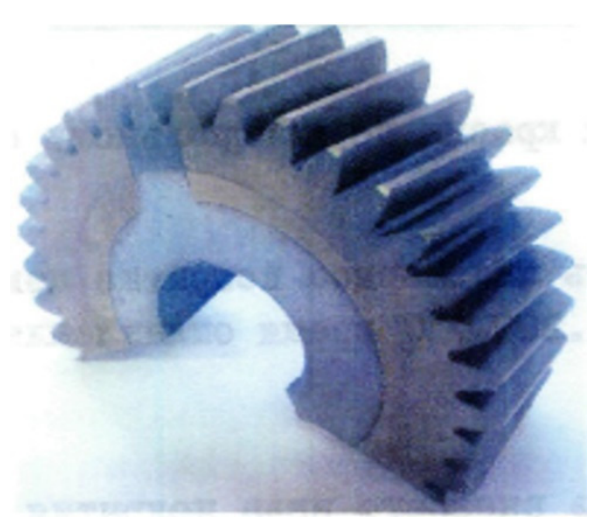

Fig. 8. Appearance of the witness sample

The results of studies of plasma nitriding of a gear wheel with plasma nitriding and Avinit C310 coating are described in [11].

Measurement of the hardness of the nitrided layer, starting from the edge of the tooth, was performed with a resolution of $0.05 \mathrm{~mm}$ to a depth of $0.5 \mathrm{~mm}$.

The hardness of the nitrided layer is given in table 3 .

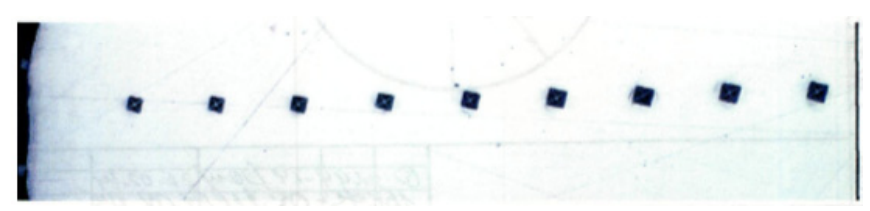

Fig. 9. Imprints of microhardness measurements (the section is not etched) 
Table 3. The hardness of the nitrided layer

\begin{tabular}{|c|c|c|}
\hline No & $\begin{array}{c}\text { Distance from } \\
\text { the edge, } \mathrm{mm}\end{array}$ & Hardness, $\mathrm{H} \mu$, in parentheses HRC \\
\hline 1 & 0,05 & $603,644(57,5) \quad 633(57)$ \\
\hline 2 & 0,1 & $612(56), 557(53), 584(54)$ \\
\hline 3 & 0,15 & $532,532(51), 516$ \\
\hline 4 & 0,20 & $524,524(50,7)$ \\
\hline 5 & 0,25 & $501(49), 501,494(49)$ \\
\hline 6 & 0,30 & $453(45,6)$ \\
\hline 7 & 0,35 & $466,453(46)$ \\
\hline 8 & 0,40 & $401(41), 391(39,8)$ \\
\hline 9 & 0,45 & 376,390, \\
\hline
\end{tabular}

The microstructure of the nitrided layer is satisfactory (Fig. 10)

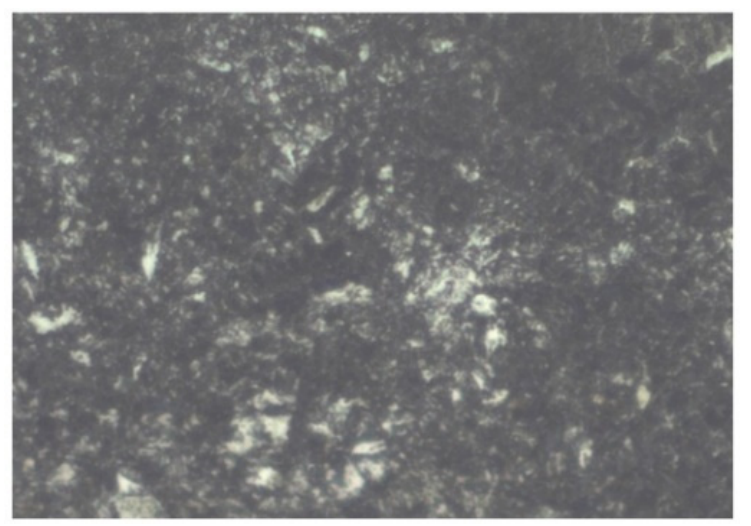

Fig. 10. The microstructure of the nitrided layer $(x 500)$

The measurements of the toothed ring before nitriding confirm the manufacture of the gear on the 4 th degree of accuracy.

Measurements of the toothed crown after nitriding and coating showed that changes in the geometry after plasma precision nitriding Avinit $\mathrm{N}$ and Avinit coating by duplex technology is not observed. Reducing the nitriding time ensures that the parameters of the gear ring gear after nitriding within the accuracy of 4 (ISO - +1328 - 1), designed for loaded gears of aircraft reducers.

The adhesion of the coating was checked by the standard method used for galvanic coatings and was satisfactory.

It is established that changes in geometry after plasma precision nitriding of Avinit N and Avinit coating by duplex technology are not observed. Avinit C310 antifriction coating with a thickness of $1.5 \mu \mathrm{m}$ does not distort the geometry of the tooth profiles. All parameters of the gear ring, made by duplex technology Avinit, meet the degree of accuracy 4 in accordance with the requirements of the technical documentation.

\section{Testing of gears made by duplex technology}

\subsection{Preliminary tests}

The results of preliminary tests of the gear wheel with plasma nitriding and Avinit C310 coating are described in [21].

The gear was tested as part of the gearbox of the AI-450M engine on the hydraulic brake stand [21]. The total operating time during the tests was 1 hour 30 minutes, of which mode - 75 minutes, on takeoff mode 6 minutes. The power transmitted by the engine in takeoff mode is $465 \mathrm{hp}$, while the torque on the gear is $22.67 \mathrm{kgf} \cdot \mathrm{m}$. The maximum specific load on the gear tooth, taking into account the end and axial overlap is $453.4 \mathrm{kgf} / \mathrm{cm}$, while the contact stresses on the surface are $121 \mathrm{kgf} / \mathrm{mm}^{2}$.

After testing, the gear was dismantled to perform defecting, magnetic powder control and measurements. If any damage to the gear, including the Avinit coating, is not detected, there are weak traces of work on the coating.

Antifriction coating Avinit C310 with a thickness of $1.5 \mu \mathrm{m}$ does not distort the geometry of the tooth profiles, in the process of the first tests in the gearbox of the AI-450M engine wear wear is not observed. Measurement of the parameters of the teeth showed a complete lack of wear.

\subsection{Test of a full-size gear wheel 4501150003-02}

Long-term tests of the gear wheel were carried out as part of the gearbox of the engine AI-450M № 450M-003 on the hydraulic brake stand of SE "Ivchenko-Progress" [21]. The operating time of the wheel was $40 \mathrm{~h}$ at a maximum voltage of $115.06\left(\mathrm{kgf} / \mathrm{mm}^{2}\right)$.

During the tests, the gear wheel 45011500003-02 was the guide for the driven wheel 45011500004-01, manufactured by standard technology (gas nitriding grinding - copper coating) (Fig. 11). After the tests, both wheels were defective. Examination of the teeth of the wheel 45011500003-02 showed no wear of the coating on the tooth profiles, however, there was wear of the coating on the corresponding teeth of the wheel 45011500004-01. Due to the small coating thickness $(2 \mu \mathrm{m})$, its wear did not affect the performance of the gear. Preliminary longterm tests of similar gears made by standard technology have shown that the wear of the copper coating on the teeth occurs only in the case of contact with foreign particles. Thus, the combination of hard and soft coating of the teeth of the two engaged wheels showed a negative result. The reason for the wear of the copper coating is probably micro-irregularities on the surface of the teeth, which in the process of sliding surfaces when engaged cut the coating. 


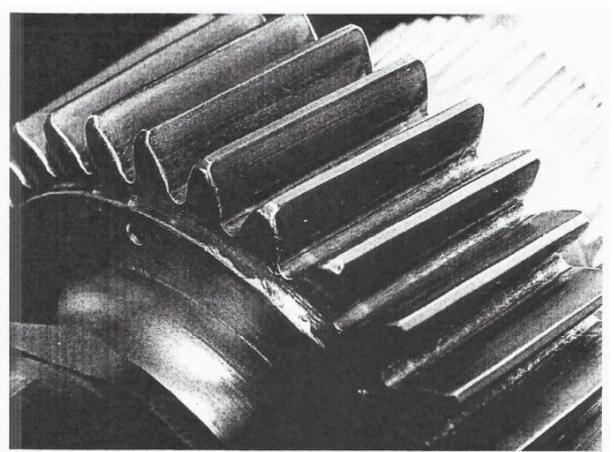

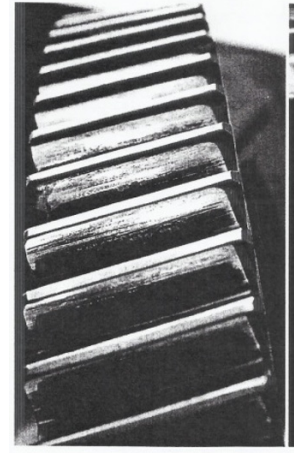

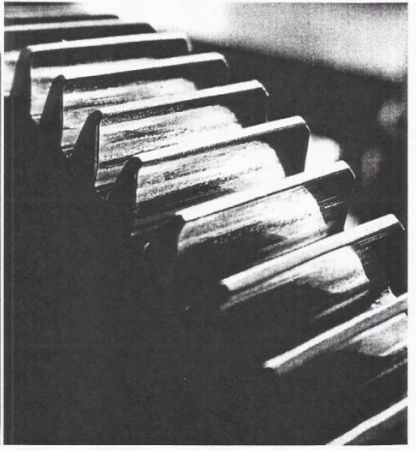

$b$

Fig. 11. Photos of gears $a$ ) gear 45011500003-02 / 4501150008-60; b) gear 45011500004-01

Thus, the gear wheel 45011500003-02 with superhard coating Avinit C310 was tested as part of the gearbox of the engine AI-450M for 40 hours. After tests of changes in the geometry of the teeth of the wheel and wear of the coating Avinit C310 was not detected, but there is wear of the copper coating of the teeth of the mating gear with the appearance of a mirror luster on the surface of the teeth.

\subsection{Joint testing of gears 4501150003-02 and 4501150004-01}

After the production of the driven gear 4501150004-01, strengthened by duplex technology Avinit, joint tests of a pair of gears 4501150003-02 and 4501150004-01 were carried out. The tests were carried out as part of the AI-450M engine on the hydraulic brake stand of Ivchenko-Progress according to the program of equivalent cyclic tests. A pair of experimental gears was installed in the engine gearbox instead of the serial wheels of the second gearbox. The total test time of the wheels was 26 hours.
After the tests, the gears are defective.

The appearance of the teeth of the wheels showed a forgery of the coating similar to that which was on the pro-

duction wheels, ie wear of the coating on only one of the wheels is not. Measurements also showed identical grinding of the teeth of both wheels.

\section{Conclusions}

1. Plasma precision technology Avinit $\mathrm{N}$ allows you to perform nitriding of the finished parts without changing the size, including gears of 4 degrees of accuracy.

2. Nitriding time of Avinit $\mathrm{N}$ is $2 . .4$ times less than with gas, with epsilon nitride phase is almost absent.

3. Coating of parts Avinit C310 increases the microhardness of the surfaces of parts and reduces the coefficient of friction, while having sufficient adhesion to the working surfaces of the teeth of the gears and tread bearings.

\section{References}

[1] Tekhnologiya proizvodstva i metody obespecheniya kachestva zubchatykh koles i peredach. SPb: Professiya, 2007.

[2] Yu.M. Lakhtin et al., Teoriya i tekhnologiya azotirovaniya, Moscow: Metallurgiya, 1991.

[3] B.N. Arzamasov et al., Ionnaya khimiko-termicheskaya obrabotka splavov, Moscow, MGU im. Baumana, 1999.

[4] Yu.S. Eliseev et al., Proizvodstvo zubchatykh koles gazoturbinnykh dvigatelei, Moscow: Vyssh. shkola, 2001.

[5] Antifriktsionnye pokrytiya rabochikh poverkhnostei shesteren i podshipnikov. Tekhnicheskii otchet, T/o No. 4/2007-CESAR, GP "Ivchenko-Progress", Zaporozh'e, 2007.

[6] Yu.S. Eliseev, V.V. Krymov, "Chto nado dlya sozdaniya dvigatelya novogo pokoleniya”, Dvigatel', No. 3 (73), pp. 2-5, 2007.

[7] I.F. Kravchenko et al., "Eksperimental'nye i teoreticheskie rezul'taty issledovaniya aviatsionnykh zubchatykh peredach dlya dvigatelei pyatogo i shestogo pokolenii”, Aviatsionno-kosmicheskaya tekhnika i tekhnologiya, No. 8 (55), pp. 129-134, 2008.

[8] O.V. Sagalovich and V.V. Sagalovich, "Sposib ionno-plazmovogo pretsiziinogo azotuvannya poverkhon' stalei ta splaviv Avinit N", No.84664, 25.10.13.

[9] A.V. Sagalovich and V.V. Sagalovich, "Sposib ionno-plazmovogo pretsiziinogo azotuvannya poverkhon' stalei ta splaviv Avinit N", No.107408, 28.12.14.

[10] A.V. Sagalovich, V.V. Popov and V.V. Sagalovich, "Plazmove pretsiziine azotuvannya Avinit N", Tekhnologicheskie sistemy, No. 4(89), pp. 16-26, 2019. 
[11] Issledovanie metodov uprochneniya razrabotki NTTs "Nanotekhnologiya", Tekhnicheskaya spravka No. 106/2015. GP "Ivchenko-Progress", Zaporozh'e, 2015.

[12] Issledovanie plazmennogo azotirovaniya shesteren. Tekhnicheskaya spravka, No. 92/2015. GP "Ivchenko-Progress", Zaporozh'e, 2015.

[13] A.V.Sagalovich et al., "Porivnyal'nii analiz vtomnoï kontaktnoï mitsnosti poverkhon', zmitsnenikh tsementuvannyam ta ionnoplazmovim azotuvannyam Avinit N”, Visnik dvigunobuduvannya. No. 1, pp. 33-45, 2020.

[14] A.V. Sagalovich et al., "Eksperimental'nye issledovaniya pokrytii tipa Avinit, Aviatsionno-kosmicheskaya tekhnika i tekhnologiya. Tekhnologiya proizvodstva letatel'nykh apparatov", T. 1, pp. 5-15, 2011.

[15] A. Sagalovych et al., "Experimental research of multicomponent multilayer ion-plasma Avinit coatings", Fizicheskaya inzheneriya poverkhnosti, T. 10, No. 4, pp. 229-236, 2012.

[16] A.Sagalovych et al., "Experimental research of multicomponent multilayer ion-plasma Avinit coatings", Fizicheskaya inzheneriya poverkhnosti, T. 11, No. 1, pp 4-17, 2013.

[17] O.V. Sagalovich et al., "Znosostiike antifriktsiine pokrittya", No. 109053, 10.07.15.

[18] A.V. Sagalovich et al., "Bagatosharove, znosostiike pokrittya", No. 108279, 10.04.15.

[19] V.Popov, A.Sagalovych and V.Sagalovych, Improving the performance, reliability and service life of aviation technology products based on the innovative vacuum-plasma nanotechnologies for application of avinit functional coatings and surfaces modification: monograph. Tallinn, Scientific Route OÜ Publ., 2020. DOI: https://doi.org/10.21303/978-9916-9516-1-3

[20] O.V. Sagalovich et al., "Vacuum-plasma protective coating for turbines blades", Mechanics and Advanced Technologies, No. 1(88), pp. 124-134 2020. http://doi.org/10.20535/2521-1943.2020.88.204675

[21] Ispytaniya pokrytiya Avinit S310 na dvigatele AI-450M. Tekhnicheskaya spravka, No. 488/2017, GP "Ivchenko-Progress", Zaporozh'e, 2017.

[22] A.V. Kononykhin et al., "Izuchenie tribologicheskikh kharakteristik mnogosloinykh Mo-S pokrytii, poluchennykh gazofaznym metodom s ispol'zovaniem metallorganicheskikh soedinenii”, Vestnik KhNADU, V. 54, pp. 44-51, 2011.

[23] A.V. Sagalovich et al., "Nanesenie pokrytii na slozhnoprofil'nye pretsizionnye poverkhnosti gazofaznym metodom (CVD)", Fizicheskaya inzheneriya poverkhnosti, T. 9, No. 3, pp. 229-236, 2011.

[24] A.V. Sagalovich et al., "Izuchenie tribologicheskikh kharakteristik mnogosloinykh Mo-S pokrytii, poluchennykh gazofaznym metodom s ispol'zovaniem metallorganicheskikh soedinenii”, Tekhnologicheskie sistemy, No. 1(58), pp. 46-54, 2012.

[25] A.Sagalovych, V. Sagalovych, "Mo-C multilayered CVD coatings", Tribology in industry, V. 35, No. 4, pp. $219-227,2013$.

[26] A. Sagalovych et al., "The Antifrictional Coatings on the Molybdenum Base", Proc. 15th Intern. Conf. on Tribology SERBIATRIB '17, Kragujevac, Serbia, 2017.

[27] A. Sagalovych et al., "Development of the chemical vapor deposition process for applying molybdenum coatings on the components in assembly and engine construction", Skhidno-Evropeis'kii zhurnal peredovikh tekhnologii (EEJET), No. 2/12(104), pp. 6-15, 2020. https://doi.org/10.15587/1729-4061.2020.201540

\title{
Застосування вакуум-плазмових технологій Avinit до виготовлення повнорозмірних високоточних шестерень.
}

\section{О. В. Сагалович, В. В. Попов, В. В. Сагалович, С. Ф. Дудник, А. Б. Єдинович}

\begin{abstract}
Анотація. Розроблено дуплексні технології Avinit, які об'єднують плазмове азотування Avinit $N$ остаточно готових високоточних деталей з подальшим нанесенням надтвердих антифрикиійних покриттів Аvinit в єдиному технологічному процеci.

Завдяки відсутності на азотуючій поверхні крихкого шару після прецизійного азотування, збереженню вихідних геометричних розмірів, які не потребують подальшої механічного доопрацювання, і сумісності прочесів плазмового високоточного азотування Avinit $N$ i вакуум-плазмового нанесення функціональних покриттів Avinit 3 дуплексні технології дозволяють забезпечити нанесення міџно-щеплених, високоякісних покриттів. Досліджено вплив дуплексного процесу на розміри деталей при плазмовому азотуванні високоточних шестерень $і$ нанесенні функціональних покриттів Аvinit C, вивчені властивості азотувального шару і параметри покриттів Avinit.

Плазмова прецизійна технологія Аvinit $N$ дозволяє виконувати азотування остаточно готових деталей без зміни розмірів, 6 тому числі шестерень по 4 ступеню точності. Час азотування Avinit $N$ в 2...4 рази менше, ніж при газовому азотуванні.

Покриття деталей Avinit C310 підвищує мікротвердість поверхонь деталей $і$ знижує коефіиієнт тертя, при иьому володіє достатньою адгезією до робочих поверхонь зубів шестерень $і$ бігових доріжок підиипників.

Проведено виготовлення високоточних зубчастих коліс за ступенем точності 4 з використанням дуплексних технологій Аvinit. Аналіз результатів показує, що в межах точності вимірювання ніяких змін профілів зубів, їх розташування на зубчастому віниі, а також розташування зубчастого віния щодо вимірювальних баз не спостерігається.

Плазмове азотування дозволяє скоротити час азотування більш ніж в два рази в порівнянні з газовим азотуванням, при цьому товщина шару тендітної фази з максимальною поверхневою твердістю забезпечується в межах заданих величин для забезпечення необхідних показників контактної і згинальної тривалої міцності при виготовленні зубчастих коліс за ступенем точності 4 без шліфування після азотування.Вимірювання зубчастого віния після азотування і покриття показа-
\end{abstract}


ли, що змін геометрії шестерні, обробленої по дуплексной технологї̈, не спостерігається. Антифрикиійне покриття Аvinit С310 товщиною 1,5 мкм не спотворює геометрію профілів зубів. Всі параметри зубчастого віния, виготовленого за дуплексною технологією Avinit, відповідають ступеню точності 4 відповідно до вимог технічної документації.

Випробування виготовлених по дуплексній технології Аvinit шестерень здійснювалося в складі редуктора двигуна AI-450M на гідротормозному стенді ДП “Івченко-Прогрес" за програмою еквівалентно-циклічних випробувань. Пара експериментальних зубчастих коліс була встановлена в редуктор двигуна замість серійних коліс другого ступеня редуктора. Сумарний час випробувань коліс склав 26 годин. Після випробувань ніяких пошкоджень шестерні, включаючи покриття Аvinit, не встановлено. Антифрикиійне покриття Аvinit C310 товщиною 1,5 мкм не спотворює геометрію профілів зубів в прочесі випробувань в складі редуктора двигуна АI-450М. Обмір параметрів зубів показав повну відсутність зносу.

Ключові слова: розробка дуплексних технологій Avinit, властивості азотувального шару, характеристики покриттів, стендові випробування виготовлених по дуплексній технології Avinit високоточних шестерень.

\section{Применение вакуум-плазменных технологий Avinit к изготовлению полноразмерных высокоточных шестерен.}

\section{А.В. Сагалович, В.В. Попов, В.В. Сагалович, С.Ф. Дудник, А.Б. Единович.}

Аннотация. Разработаны дуплексные технологии Аvinit, объединяющие плазменное азотирование Аvinit $N$ окончательно готовых высокоточных деталей с последующим нанесением сверхтвердых антифрикиионных покрытий Avinit в едином технологическом процессе

Благодаря отсутствию на азотируемой поверхности хрупкого слоя после преицизинного азотирования, сохранению исходных геометрических размеров, не требуюших дальнейшей механической доработки, и совместимости прочессов плазменного прецизионного азотирования Avinit $N$ и вакуум-плазменного нанесения функииональных покрытий Avinit $C$ дуплексные технологии позволяют обеспечить нанесение прочносцепленных, высококачественных покрытий.

Исследовано влияние дуплексного процесса на размеры деталей при плазменном азотировании высокоточных шестерен и нанесении функииональных покрытий Avinit C, изучены свойства азотированного слоя и параметры покрытий Avinit.

Плазменная прецизионная технология Avinit N позволяет выполнять азотирования окончательно готовых деталей без изменения размеров, в том числе шестерен по 4 степени точности. Время азотирования Avinit $N$ в 2 - 4 раза меньше, чем при газовом азотировании. Покрытие деталей Avinit С310 повышает микротвердость поверхностей деталей и снижает коэффиииент трения, при этом обладает достаточной адгезией к рабочим поверхностям зубьев шестерен и беговых дорожек подиипников. Проведено изготовление высокоточных зубчатых колес по степени точности 4 с использованием дуплексных технологий Avinit. Анализ результатов показывает, что в пределах точности измерения никаких изменений профилей зубьев, их расположение на зубчатом венце, а также расположение зубчатого вениа относительно измерительных баз не наблю-дается. Плазменное азотирование позволяет сократить время азотирования более чем в два раза по сравнению с газовым азотированием, при этом толщина слоя хрупкой фазы с максимальной поверхностной твердостью обеспечивается в пределах заданных величин для обеспечения необходимых показателей контактной и изгибной длительной прочности при изготовлении зубчатых колес по степени точности 4 без шлифовки после азотирования.

Измерения зубчатого вениа после азотирования и покрытия показали, что изменений геометрии шестерни, обработанной по дуплексной технологии, не наблюдается. Антифрикционное покрытие Avinit C310 толщиной 1,5 мкм не искажает геометрию профилей зубьев. Все параметры зубчатого венца, изготовленного по дуплексной технологии Avinit, соответствуют степени точности 4 соответствии с требованиями технической документации.

Испытания изготовленных по дуплексной технологии Аvinit шестерен осуществлялось в составе редуктора двигателя АИ$450 М$ на гидротормозном стенде ГП “Ивченко-Прогресс" по программе эквивалентно-чиклических испытаний. Пара экспериментальных зубчатых колес была установлена в редуктор двигателя вместо серийных колес второй ступени редуктора. Суммарное время испытаний колес составило 26 часов. После испытаний никаких повреждений шестерни, включая покрытие Avinit, не установлено. Антифрикиионное покрытие Avinit C310 толщиной 1,5 мкм не искажает геометрию профилей зубьев в процессе испьтаний в составе редуктора двигателя АИ-450М. Обмер параметров зубов показал полное отсутствие износа.

Ключевые слова: разработка дуплексных технологий Avinit, свойства азотированного слоя, характеристики покрытий, стендовые испытания изготовленных по дуплексной технологии Avinit высокоточных шестерен. 